\title{
PENERAPAN STRATEGI PEMBELAJARAN ONE QUESTION ONE MINUTE UNTUK MENINGKATKAN KEMAMPUAN SISWA DALAM PEMECAHAN MASALAH IPA DI KELAS 9A SMP NEGERI 1 PENAJAM PASER UTARA
}

\author{
Muhammad Hanafi \\ SMP Negeri 1 Penajam Paser Utara
}

\begin{abstract}
ABSTRAK
Penelitian ini bertujuan untuk meningkatkan hasil belajar siswa dalam mata pelajaran IPA melalui strategi one question one minute di kelas 9A SMP Negeri 1 Penajam Paser Utara Tahun Pelajaran 2018/2019. Penelitian ini merupakan penelitian tindakan kelas, data yang diperoleh melalui pengamatan dan dokumentasi. Data tentang respon minat, motivasi, dan hasil belajar dalam hal kemampuan menyelesaikan masalah IPA diperoleh melalui dari instrumen angket dan tes, selanjutnya di analisis secara kualitatif dan kuantitatif. Dari hasil penelitian menunjukkan bahwa: 1) penerapan strategi one question one minute dapat meningkatkan kemampuan siswa dalam memecahkan masalah IPA. 2) Respon siswa berupa minat dan motivasi model ARSC di kategorikan cukup baik. Dari hasil penelitian ini dapat disimpulkan bahwa penerapan strategi pembelajaran one question one minute dapat meningkatkan kemampuan siswa dalam pemecahan masalah IPA. Hal ini terlihat dari peningkatan nilai siswa yang lulus sesuai KBM yang ditetapkan oleh guru.
\end{abstract}

Kata kunci: Strategi one question one minute, pemecahan masalah

\section{PENDAHULUAN}

Mata pelajaran IPA di kurikulum 2013 di SMP Negeri 1 Penajam Paser Utara, memberikan alokasi waktu sebanyak 5 jam perminggu, dengan 40 menit per jam. Dengan alokasi waktu tersebut, belum menjamin bahwa angka ketuntasan belajar minimal pasti tercapai dalam pembelajaran. Hal ini terbukti rendahnya kemampuan siswa dalam menyelesaikan atau memecahkan masalah IPA dengan hasil belajar yang rendah. Salah satu masalah dalam pembelajaran IPA di SMP Negeri 1 Penajam Paser Utara adalah rendahnya kemampuan siswa dalam memecahkan masalah, khususnya soal non rutin atau terbuka (open ended).

Berdasarkan pada indikator Suhu dan Perubahannya dalam kehidupan (materi di kelas 9 SMP ) yang dilakukan penulis di kelas 9A SMP Negeri 1 Penajam Paser Utara pada tahun pelajaran 2018/2019, siswa masih lemah dalam hal menyelesaikan soal-soal yang menekankan pada kemampuan menyelesaikan tugas pemecahan masalah. Kelemahan siswa dalam menyelesaikan soal pemecahan masalah terutama dalam hal: (1) memahami informasi soal, artinya siswa mengalami kesulitan dalam menuliskan hal yang diketahui dan yang ditanyakan pada soal, (2) merencanakan penyelesaian yang sesuai dalam menyelesaikan soal, (3) menggunakan rumus yang tepat untuk menyelesaikan soal, (4) menghitung dalam mengerjakan soal, (5) kepercayaan diri dalam mengerjakan soal. 


\section{Tujuan Penelitian}

Sesuai dengan permasalahan yang ada, penelitian ini bertujuan untuk:

1. Ingin meningkatkan kemampuan siswa dalam pemecahan masalah IPA di kelas 9A di SMP Negeri 1 Penajam Paser Utara melalui strategi pembelajaran one question one minute tahun pelajaran 2018/2019

2. Ingin mengetahui motivasi dan minat belajar siswa melalui strategi pembelajaran one question one minute di kelas 9A SMP Negeri 1 Penajam Paser Utara tahun pelajaran 2018/2019

\section{Kajian Pustaka}

Sutawijaya (Siswono, 1999: 2) mengatakan bahwa penyebab kesulitan siswa menyelesaikan soal pemecahan masalah dapat berupa kelemahan dalam pemahaman konsep dan prinsip, tidak terampil melaksanakan prosedur dan formula yang diperlukan untuk memecahkan soal. Untuk mengatasinya, Sutawijaya yang merujuk pada pendapat Cars menyarankan setiap siswa atau kelompok siswa diberanikan diri untuk membuat pertanyaan. Cara ini yang dikenal dengan istilah pengajuan pertanyaan (problem posing).

pengajuan pertanyaan dapat meningkatkan pemikiran siswa, keterampilan-keterampilan

memecahkan masalah, sikap, dan kepercayaan dalam IPA dan pemecahan masalah matematis, serta memberikan kontribusi terhadap pemahaman yang lebih luas terhadap konsep IPA. Selain itu, hasil penelitian yang dilakukan oleh Silver dan Cai (Christou, et.al: 2005) menunjukkan bahwa kemampuan pemecahan masalah siswa berkorelasi tinggi dengan kemampuan pengajuan pertanyaan.

$$
\text { Pengajuan pertanyaan }
$$

merupakan suatu tugas yang meminta siswa untuk membuat menyelesaikan pertanyaan berdasarkan informasi yang diberikan dan kemudian menyelesaikannya. Dengan membuat menyelesaikan pertanyaan di rumah, dapat membantu siswa untuk mengatasi kesulitan dalam memahami pertanyaan atau soal. Sedangkan dengan menyelesaikan soal atau pertanyaan, siswa dapat dilatih untuk mengingat prosedur menyelesaikan soal sehingga jika diberikan soal yang serupa dengan soal itu, ia dapat mengingatnya serta lebih terampil dalam menggunakan prosedur atau algoritma penyelesaian. Salah satu model tugas pengajuan pertanyaan dikembangkan oleh Christou, et.al. yang diberi nama pengajuan pertanyaan berdasarkan taksonomi empirik.

Taksonomi empirik ini dikembangkan dengan berdasarkan proses berpikir yang terjadi pada saat siswa menyelesaikan tugas pengajuan pertanyaan. Taksonomi empirik menurut Christou, et. al (2005) terdiri dari empat jenis informasi, yaitu editing quantitative information, selecting quantitative information, comprehending and organizing quantitative information, dan translating quantitative information. Editing quantitative information berkaitan dengan tugas yang meminta siswa untuk mengajukan pertanyaan tanpa suatu batasan dari informasi berupa cerita atau petunjuk yang disediakan.

Petunjuk ini dapat berupa data, tabel, dan gambar yang menujukkan suatu situasi. Selecting quantitative information berkaitan dengan tugas yang meminta siswa untuk mengajukan pertanyaan yang sesuai dengan jawaban khusus yang disediakan. Dari empat jenis tugas yang diberikan, siswa mengatakan tugas yang berkaitan dengan editing (diberikan gambar), membaca tabel, merupakan tugas yang 
sulit. Selain itu, siswa dapat menyelesaikan pertanyaan yang dibuat oleh guru meslkipun belum sempurna.

PERMENDIKBUD No. 64

Tahun 2013, bahwa kompetensi untuk siswa kelas 7 adalah menunjukkan sikap logis, kritis, analitis, cermat dan teliti, bertanggung jawab, responsif dan tidak mudah menyerah dalam memecahkan masalah. Pada kurikulum 2013 (Anggraena, dkk, 2012) dijelaskan pula bahwa fokus pembelajaran IPA salah satunya adalah kemampuan memecahkan masalah. Oleh karena itu, setiap guru yang mengelola pembelajaran IPA perlu melatih keterampilan siswa dalam memecahkan masalah.

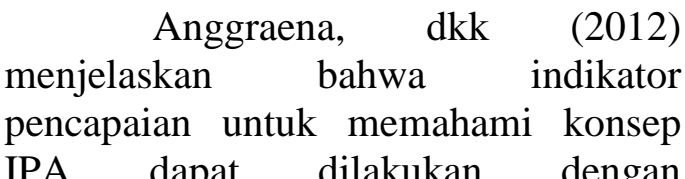
menyajikan konsep dalam berbagai macam bentuk representasi matematis, misal tabel, grafik, diagram, gambar, sketsa, model IPA atau cara lainnya. Sedangkan untuk mencapai tujuan mengembangkan penalaran, siswa perlu diberikan soal non rutin yang dalam menyelesaikannya diperlukan usahausaha tambahan yang perlu modifikasi dengan indikator pencapaian antara lain memahami masalah dan menyajikan suatu rumusan masalah. Strategi pembelajaran dengan pengajuan pertanyaan dipandang relevan dengan tujuan ini.

\section{Teoritik Strategi Pembelajaran}

Strategi pembelajaran one
question one minute untuk meningkatkan kemampuan pemecahan masalah adalah suatu strategi pembelajaran yang berorientasi pada pengajuan pertanyaan sebagai fokus pembelajarannya dan menekankan belajar aktif secara mental.
Strategi pembelajaran ini didasarkan pada teori sebagai berikut:

Teori Piaget; menjelaskan bahwa pengetahuan berasal dari adaptasi individu pada lingkungannya (Siswono, 2008:60). Berdasarkan pandangan ini, pembelajaran memberi kesempatan siswa untuk mengkonstruksi konsep yang sedang dipelajari. Belajar adalah proses mental yang aktif untuk mencapai, mengingat dan menggunakan pengetahuan. Menyelesaiakan pertanyaan yang di berikan guru mendorong siswa untuk mengkonstruksi konsep berdasarkan pengetahuan yang sudah dimilikinya. Pengajuan pertanyaan juga mendorong siswa untuk dapat menyelesaikannya berdasarkan pengetahuan yang sudah dimilikinya. Dalam pandangan ini, perkembangan intelektual seseorang berdasar pada perkembangan biologisnya. Artinya, dalam penyelesaian pertanyaan, tugas yang diberikan harus memperhatikan masalah yang sesuai dengan perkembangan usia siswa SMP.

Teori konstruktivis; Brooks dan Brooks (Tim, 2011:5) menjelaskan bahwa belajar dipandang sebagai penyusunan pengetahuan dari pengalaman konkrit, aktivitas kolaboratif, dan reflektif serta interpretasi. Penyelesaian pertanyaan memberikan pengalaman kepada siswa untuk membuat pertanyaan berdasarkan informasi yang diberikan sekaligus menyelesaikannya.

Siswa mempunyai pengalaman untuk menyelesaikan pertanyaan yang dibuatnya sendiri yang pasti ia pahami, sehingga diharapkan siswa dapat menerapkan pengalaman itu untuk menyelesaikan soal pemecahan masalah lainnya. Pengajuan pertanyaan juga memberikan kesempatan kepada siswa untuk belajar secara kolaboratif. Teori pengajuan pertanyaan menurut 
(Christou, et.al, 2005), Christou, et.al, (2005), Roberts (Upu, 2003: 7), Dillon (Upu, 2003), dan intinya menjelaskan tentang pentingnya peranan pengajuan pertanyaan dalam meningkatkan kemampuan pemecahan masalah.

\section{METODE PENELITIAN}

Setting Penelitian

Penelitian ini dilakukan di SMP Negeri 1 Penajam Paser Utara, Kabupaten Penajam Paser Utara, Provinsi Kalimantan Timur. Sedangkan subyek penelitian siswa kelas 9A yang berjumlah 30 siswa

\section{Rancangan Penelitian}

Dalam penelitian ini, penulis menggunakan penelitian tindakan kelas (CAR). CAR merupakan penelitian sederhana untuk memecahkan masalah yang dilakukan dalam proses pembelajaran. Penelitian dilakukan dengan mengikuti beberapa langkah, yaitu: studi pendahuluan sebelum menganalisis dan mengindentifikasi masalah, diikuti dengan perencanaan, pelaksanaan, observasi, dan refleksi.

\section{Perencanaan}

Peneliti menyiapkan strategi pembelajaran, peneliti menjelaskan tujuan pembelajaran, peneliti menjelaskan cara pemecahan masalah IPA, peneliti memberikan saran yang dibutuhkan siswa. Pada tahap perencanaan yang dilakukan peneliti adalah
a) Menyiapkan pembelajaran
perangkat
b) Menentukan pembelajaran
materi
c) Membuat desain pembelajaran
d) Menyusun Instrumen respon minat siswa terhadap pembelajaran IPA
e) Menyusun isntrumen penilaian
f) Menyiapkan pembelajaran dengan media power point

\section{Kriteria Keberhasilan}

Indikator keberhasilan dalam penelitian ini adalah tanda untuk menentukan keberhasilan meningkatnya kemampuan pemecahan masalah pembelajaran IPA pada materi suhu dan perubahannya. Ada dua indikator keberhasilan dalam strategi ini selama proses belajar mengajar.

1. $80 \%$ siswa mampu meningkatkan kemampuannya dalam pemecahan masalah pembelajaran IPA dengan skor > 70

2. Siswa menikmati proses belajar mengajar, melalui angket minat dan motivasi belajar siswa

\section{Implementasi Tindakan}

Pada tahap implementasi
tindakan peneliti melaksanakan
pembelajaran yang dimulai dengan
memberikan pengetahuan prosedural
sesuai dengan materi pelajaran Selanjutnya peneliti memberikan pengetahuan awal materi pelajaran, peneliti penerapan strategi pembelajaran one question one minute yaitu dengan menggunakan media power point yang berisi soal-soal IPA, setiap soal memiliki waktu yang telah ditentukan atau dibatasi waktunya.

Waktu dalam media power point di setting terhitung mundur dari 60 sekon berkurang sampai waktunya habis. Selanjutnya soal berikutnya akan muncul dan memiliki waktu yang sudah ditentukan, dan begitu selanjutnya. Soal yang sudah terlihat tidak akan terulang lagi, siswa tahu yang harus dilakukannya dan harus menggunakan waktu sebaik-baiknya.

\section{Observasi}

Dengan menggunakan pedoman observasi yang telah direncanakan, observer melakukan pengamatan:

a) Apakah rencana yang telah ditetapkan dilaksanakan atau tidak 
b) Jika dilaksanakan, apakah pelaksanaannya sesuai dengan rencana yang telah dibuat.

c) Jika sesuai dengan yang direncanakan, apakah pelaksanaanya itu berdampak terhadap siswa.

Dalam tahap ini, peneliti mengumpulkan informasi data yang terkait dengan kriteria keberhasilan. Siswa yang sedang menyelesaikan soal, diamati menggunakan catatan lapangan. Untuk mengumpulkan data yang terkait dengan kreteria keberhasilan, peneliti mengambil nilai test. Test diberikan pada akhir setiap siklus. Uji keberhasilan pemecahan masalah atau meningkatnya kemampuan pemecahan masalah pembelajaran IPA dengan meminta para siswa membuat deskripsi tentang kemampuan pemecahan masalah pembelajaran IPA. Kemudian peneliti menilai menggunakan lembar observasi untuk mendapatkan suasana kelas dan kemampuan pemecahan masalah IPA.

\section{Refleksi}

Data yang diperoleh dari hasil observasi selama proses pembelajaran dilakukan analisis dan dilakukan refleksi sebagai bahan penyusunan rencana tindakan pada siklus berikutnya. Pada tahap refleksi ada beberapa kriteria yang dijadikan sebagai rambu-rambu keberhasilan, misalnya: apakah proses pembelajaran sudah sesuai dengan rencana dan bagaimana pengaruhnya strategi pembelajaran one question one minute terhadap peningkatan kemampuan pemecahan masalah pembelajaran IPA di kelas 9A SMP Negeri 1 Penajam Paser Utara Tahun Pelajaran 2018/2019

\section{Pengumpulan Data}

Pengumpulan data pada penelitian ini dilakukan dengan cara sebagai berikut:
1. Dokumentasi Nilai harian sebelumnya, digunakan dasar acuan perbandingan pada hasil tes akhir siklus I.

2. Tes ulangan lisan, baik secara individu maupun klasikal yang dilakukan di kelas setelah pembelajaran.

3. Observasi, menggunakan tabel pedoman observasi untuk mengetahui tingkat aktivitas siswa dan aktivitas guru pada saat pembelajaran berlangsung

4. Tes hasil belajar setiap akhir siklus, untuk mengetahui peningkatan kemampuan pemecahan masalah pembelajaran dengan bentuk soal uraian

\section{Analisis Data}

Pengumpulan data yang berupa katakata/kalimat dari catatan lapangan dan hasil wawancara. Menurut Saehan Munchith (2008:57) membagi dua hasil belajar yaitu: (a) instructional effect yaitu seorang siswa setelah melakukan proses pembelajaran langsung dapat memahami segala materi yang dipelajari. (b) Nuturant effect yaitu siswa yang belajar tidak langsung memahami yang dipelajari, setelah kurun waktu tertentu mereka baru memahami apa yang dipelajari.

Data tentang angket respon yang berupa minat dan motivasi dianalisis dengan menghitung rata-rata tiap kondisi Attention (perhatian), Relevance (relevansi), Confidence (percaya diri), Satisfaction (kepuasan), kriteria positif dan negatif. Nilai rata-rata tersebut dikonfersikan dengan kategori sebagai berikut:

$$
\begin{aligned}
& 1,00-1,49 \text { tidak baik } \\
& 1,50-2,49 \text { kurang baik } \\
& 2,50-3,49 \text { cukup baik } \\
& 3,50-4,49 \text { baik } \\
& 4,50-5,00 \text { sangat baik }
\end{aligned}
$$

Dengan asumsi, siswa mengisi angket memberikan jawaban secara jujur. 


\section{PEMBAHASAN}

Penelitian yang dilakukan terhadap siswa kelas 9A SMP Negeri 1 Penajam Paser Utara tahun pelajaran 2018/2019 sebanyak 2 siklus hasil penelitian sebagai berikut:

\section{Siklus I}

1. Perencanaan Tindakan

Tahap perencanaan tidakan yang dilakukan pada siklus I meliputi pembuatan perangkat pembelajaran, pembuatan media pembelajaran, pembuatan instrumen dan lembar observasi. Pembuatan instrumen dan lembar observasi peneliti digunakan untuk mengetahui sejauh mana peneliti yang tidak lain adalah guru yang mengajar di kelas dengan strategi pembelajaran one question one minute. Sedangkan instrumen dan lembar observasi siswa digunakan untuk melakukan pengamatan dan penilaian keberhasilan siswa.

2. Pelaksanaan Tindakan

Pelaksanaan tindakan pada siklus pertama dilaksanakan sebanyak 3 kali pertemuan. Pertemuan I Tindakan yang dilakukan pada pembelajaran ini dilakukan pada hari Selasa tanggal 4 September 2018 pukul 07:30 - 09:30 mengacu pada perencanaan tindakan yang telah dibuat. Pertemuan II tindakan yang dilakukan pada pembelajaran ini dilaksanakan pada hari Rabu, 5 September 2018 pukul 07:30 08:50 mengacu pada perencanaan tindakan yang telah dibuat. Materi ajar yang disajikan pada pertemuan II mengenai materi pengembangan dalam kehidupan dan materi rumus-rumus untuk penyelesaikan permasalahan soal IPA. Pertemuan III Tindakan yang dilakukan pada pembelajaran ini dilaksanakan hari Selasa, 11 September 2018 Pukul 07:30 - 09:30 mengacu pada perencanaan tindakan yang telah dibuat. Materi ajar yang disajikan pada pertemuan III adalah indikator I sampai dengan indikator 4 yaitu ulangan harian II.

3. Hasil Pengamatan

Aspek yang diamati terhadap perilaku peneliti meliputi keterampilan membuka pelajaran (A), penerapan strategi pembelajaran one question one minute dalam pembelajaran, (B) kemampuan pemecahan masalah IPA siswa dalam menjawab soal atau pertanyaan dari guru, (C) keterampilan menutup pelajaran, (D) pengamatan yang dilakukan observer terhadap kinerja peneliti.

Pembelajaran yang dilakukan belum sesuai harapan dan masih terdapat beberapa kekurangan. Sebagian besar aspek yang diamati observer dilakukan oleh peneliti dengan baik, kecuali keterampilan membuka pelajaran dan awal pemberian motivasi kepada siswa, hal ini diakibatkan peneliti tidak mereview $\mathrm{PR} /$ tugas dan pelajaran sebelumnya. Kerampilan peneliti dalam mengajukan pertanyaan ke siswa sehingga siswa dapat meningkatkan kemampuan pemecahan masalah cukup bagus. Keterampilan peneliti menutup pelajaran termasuk kategori sangat baik, kinerja guru sebagai peneliti dilakukan rata-rata dilakukan dengan baik.

Tingkat kemampuan siswa dalam hal pemecahan masalah IPA terhadap materi ajar pada siklus I masih belum menunjukkan perubahanyang signifikan,masih terjadi kebingungan dalam menjawab soal-soal yang di ajukan oleh peneliti. Kebingungan siswa di karenakan, masih belum menguasai materi yang di sampaikan oleh guru, kebingungan di sebabkan juga antara soal dan jawaban tidak selaras. Tingkat penguasaan siswa pada materi suhu dan perubahannya nilai ulangan termasuk jurang baik, nilai observasi minat siswa terhadap pelajaran IPA rata-rata cukup. 


\section{Refleksi}

Setelah dilakukan refleksi berdasarkan hasil pengamatan melalui diskusi anatara [engamat dan observer disimpulkan bahwa kinerja peneliti pada siklus I perlu ditingkatkan terutama keterampilan dalam hal membuka pelajaran dan awal pemberian motivasi pada siswa. Peneliti perlu melakukan beberapa perbaikan hasil pembelajaran siswa pada siklus II

\section{Siklus II}

1. Perencanaan Tindakan

Perencanaan tindakan yang telah dibuat sebelumnya mengalami beberapa perbaikan yang merupakan hasil refleksi pada siklus sebelumnya meskipun ada beberapa siswa yang sudah bisa meningkatkan kemampuannya dalam memecahkan masalah IPA dengan strategi pembelajaran one question one minute. Peneliti tetap memberikan bimbingan yang direcanakan terlebih dahulu sehingga memberi kesempatan siswa untuk berpartisipasi dalam setiap kegiatan belajar mengajar.

2. Pelaksanaan Tindakan

Tindakan penelitian ini mengacu pada masukan dari pelaksanaan tindakan siklus-siklus sebelumnya. Pertemuan 4 tindakan yang dilakukan pada pembelajaran ini dilaksanakan pada hari Selasa, 18 September 2018 Pukul 07:30 - 09:30 mengacu pada perencanaan tindakan yang telah dibuat, materi ajar yang diberikan suhu dan perubahannya. Pertemuan 5 tindakan yang dilakukan pada pembelajaran ini dilaksanakan pada hari Rabu, tanggal 19 November 2018 Pukul 07:30 - 08:50 mengacu pada perencanaan tindakan yang telah dibuat materi ajar yang disajikan pada pertemuan 5 mengenai menjelaskan bagaimana caranya menyelesaikan soalsoal secara bertahap. Sedangkan pada pertemuan 6 tindakan yang dilakukan pada pembelajaran ini dilaksanakan pada hari Selasa, 25 November 2018 pada Pukul 07:30 - 09:30 yang mengacu pada perencanaan tindakan yang telah dibuat. Materi ajar yang disajikan pada pertemuan 6 adalah indikator I samapai dengan indikator 4 yaitu ulangan harian II.

3. Hasil Pengamatan

Upaya untuk meningkatkan kinerja peneliti telah benar-benar dilakukan melalui berbagai tahap refleksi dan perbaikan. Pengamatan yang dilakukan oleh observer pada kinerja peneliti, ratarata setiap aspek pengamatan yang terdiri dari keterampilan membuka pelajaran, penerapan strategi pembelajaran one question one minute dalam pembelajaran, peningkatan kemampuan siswa dalam menyelesaikan/mecahkan permasalahan IPA, keterampilan peneliti dalam menutup pelajaran kategori sangat baik,

Kinerja peneliti belum sepenuhnya sesuai harapan, akan tetapi tindakan yang dilaksanakan mengalami peningkatan secara bertahap mulai dari siklus I sampai pada siklus II. Peningkatan kinerja peneliti telah diupayakan melalui diskusi pada tahap refleksi setiap siklusnya dan usaha perbaikan perencanaan tindakan pada siklus berikutnya. Dampak yang diharapkan dari peningkatan kinerja peneliti adalah meningkatnya kemampuan siswa dalam memecahkan/menyelesaikan soal IPA. Nilai observasi dan nilai ulangan yang diperoleh siswa terbasik kategori cukup baik. Perubahan yang terjadi sangat signifikan untuk nilai ulangan mengalami kenaikan.

4. Refleksi

Berdasarkan temuan pada siklus II dan hasil diskusi guru peneliti dengan observer disimpulkan bahwa peningkatan kinerja guru dengan menggunakan strategi pembelajaran one question one minute berdampak meningkatnya hasil belajar siswa, 
meningkatnya kemampuan siswa dalam memecahkan /menyelesaikan masalah IPA. Siswa memiliki minat dan motivasi cukup dalam pembelajaran IPA, apabila dalam menyampaikan materi dikemas sedemikian rupa sehingga menarik bagi siswa dan diusahakan ada variasi dalam menyajikan materi pembelajaran. Peran pembimbingan dalam menyelesaikan atau memecahkan soal tidak dapat diabaikan.

Meningkatnya kemampuan siswa dalam menyelesaikan/memecahkan soal IPA sering terjadi dan dijumpai jawaban tidak sehat, sehingga diperlukan tindakan antisipasi berupa penanganan sesegera mungkin agar tindakan yang dilakukan semaksimal mungkin sesuai perencanaan yang dibuat. Hasil penelitian ini belum belum berakhir, dan belum hasil akhir penelitian tindakan kelas yang dilakukan, sehingga masih perlu adanya tindak lanjut melalui perencanaan yang lebih baik.

\section{Analisis Data Siklus I}

Analisis data yang digunakan dalam penelitian ini, yaitu analisis analisis kuantitatif dan analisis kualitatif. Analisis kualitatif lebih ditekankan pada hasil tes akhir siklus I, sedangkan analisis kualitatif lebih ditekankan pada hasil observasi, wawancara, pencatatan dokumen, dan angket. Hasil analisis kualitatif dapat memberikan informasi prosentase keberhsilan siswa, sedangkan analisis kualitatif dapat memberikan informasi seberapa hasil belajar dan motivasi belajar siswa terhadap pembelajaran IPA.

Hasil dari kedua analisis tersebut memberikan informasi efektif tidaknya suatu pembelajaran yang telah dilaksanakan. Jika kriteria keefektifan pembelajaran tercapai maka pembelajaran siklus Idikatakan tuntas. Namun, jika hasil analisis tersebut memperlihatkan pembelajaran kurang efektif maka perlu dilakukan tindakan siklus II untuk memperbaiki kekurangkurangan yang ada pada siklus I sampai pembelajaran tersebut tuntas.

\section{Analisis Kuantitatif}

Tes akhir siklus 1 yang dilaksanakan pada hari Rabu, 12 September 2018. Berikut ini disajikan hasil tes akhir siklus 1 dalam tabel.

\begin{tabular}{|l|lr|c|}
\hline No & Keterangan & $\begin{array}{c}\text { Jumalah } \\
\text { siswa }\end{array}$ \\
\hline 1 & $\begin{array}{l}\text { Siswa dengan } \\
\text { nilai dibawah } \\
\text { minimal 70 }\end{array}$ & 23 \\
& $\begin{array}{l}\text { Siswa dengan } \\
\text { nilai diatas } \\
\text { minimal 70 }\end{array}$ & \\
\hline
\end{tabular}

Dari tabel terlihat bahwa prosentase siswa yang mendaptkan nilai minimal 70 sebanyak 27 siswa atau 76,66\% dan siswa yang mendapatkan nilai dibawah minimal 70 sebanyak 7 siswa atau $23,33 \%$. Hal ini menyebabkan pembelajaran pada siklus I tidak sesuai dengan ketuntasan belajar minimal sehingga perlu tindakan ke siklus berikutnya supaya hasil yang diharapkan sesuai dengan ketuntasan belajar minimal yang diharapkan.

1. Analisis Kualitatif

Hasil observasi seluruh tindakan dalam siklus I dapat dilihat selengkapnya pada tabel berikut:

Minat siswa terhadap pembelajaran

Motivasi siswa terhadap pembelajaran

\begin{tabular}{|l|c|c|c|c|c|c|c|c|}
\hline \multirow{2}{*}{ Ket } & \multicolumn{7}{|c|}{ KRITERIA } \\
\cline { 2 - 9 } & \multicolumn{4}{|c|}{ POSITIP } & \multicolumn{4}{|c|}{ NEGATIF } \\
\hline Model & A & R & C & S & A & R & C & S \\
\hline skor & 3,15 & 3,32 & 3,41 & 3,07 & 2,30 & 2,40 & 3,03 & 2,35 \\
\hline \multirow{2}{*}{ Kategori } & $\begin{array}{c}\text { C. } \\
\text { Baik }\end{array}$ & $\begin{array}{c}\text { C } \\
\text { Baik }\end{array}$ & $\begin{array}{c}\text { C. } \\
\text { Baik }\end{array}$ & $\begin{array}{c}\text { C. } \\
\text { Baik }\end{array}$ & $\begin{array}{c}\text { C. } \\
\text { Baik }\end{array}$ & $\begin{array}{c}\text { C. } \\
\text { Baik }\end{array}$ & $\begin{array}{c}\text { C. } \\
\text { Baik }\end{array}$ & Baik \\
\hline
\end{tabular}

\section{Analisis Data Siklus II}

1. Analisis Kuantitatif

Tes akhir siklus II dilaksanakan pada hari Selasa, 2 Oktober 2018. Berikut disajikan hasil tes akhir siklus II 


\begin{tabular}{|l|l|c|}
\hline No & \multicolumn{1}{|c|}{ Keterangan } & Jml siswa \\
\hline 1 & $\begin{array}{l}\text { Siswa dengan nilai } \\
\text { dibawah minimal 70 }\end{array}$ & 5 \\
& $\begin{array}{l}\text { Siswa dengan nilai } \\
\text { diatas minimal 70 }\end{array}$ & \\
\hline
\end{tabular}

Terlihat pada tabel bahwa prosentase siswa yang mendapatkan nilai minimal 70 sebanyak $83,33 \%$ dan siswa yang mendapatkan nilai dibawah 70 sebanyak $16,66 \%$. Hal ini menunjukkan bahwa pembelajaran pada siklus II sudah sesuai dengan ketuntasan belajar minimal.

2. Analisis Kualitatif

Hasil analisis observasi selama siklus II dapat dilihat pada tabel berikut:

Minat siswa terhadap pembelajaran

\begin{tabular}{|c|c|c|c|c|c|c|c|c|}
\hline \multirow{3}{*}{$\frac{\text { Ket }}{\text { Model }}$} & \multicolumn{8}{|c|}{ KRITERIA } \\
\hline & \multicolumn{4}{|c|}{ POSITIP } & \multicolumn{4}{|c|}{ NEGATIF } \\
\hline & A & $R$ & $\mathrm{C}$ & S & A & $R$ & C & $S$ \\
\hline skor & 3,46 & 3,74 & 3,8 & 3,67 & 2,33 & 2,88 & 3,013 & 2,55 \\
\hline Kategori & $\begin{array}{c}\text { C. } \\
\text { Baik }\end{array}$ & Baik & Baik & Baik & $\begin{array}{c}\text { C. } \\
\text { Baik }\end{array}$ & $\begin{array}{c}\text { C. } \\
\text { Baik }\end{array}$ & $\begin{array}{c}\mathrm{C} \\
\text { Baik }\end{array}$ & $\begin{array}{c}\text { C. } \\
\text { Baikk }\end{array}$ \\
\hline
\end{tabular}

Motivasi siswa terhadap pembelajaran

\begin{tabular}{|c|c|c|c|c|c|c|c|c|}
\hline \multirow{2}{*}{ Ket } & \multicolumn{7}{|c|}{ KRITERIA } \\
\cline { 2 - 9 } & \multicolumn{3}{|c|}{ POSITIP } & \multicolumn{4}{|c|}{ NEGATIF } \\
\hline Model & A & R & C & S & A & R & C & S \\
\hline skor & 3,69 & 3,56 & 3,35 & 3,79 & 2,5 & 2,93 & 3,25 & 2,55 \\
\hline & & & C & & & C & C & C \\
Kategori & Baik & Baik & Baik & Baik & C Baik & Baik & Baik & Baik \\
\hline
\end{tabular}

\section{KESIMPULAN}

\section{Berdasarkan}

penelitian, meningkatnya kememampuan siswa dalam pemecahan masalah IPA secara mandiri. Hal ini dapat dilihat dari hasil ketuntasan belajar minimal.

2. Strategi pembelajaran one question one minute, dapat membantu guru dalam mengelolah kelas dan dapat diterapkan pada hampir semua mata pelajaran dengan catatan kompetensi dasar yang disajikan memiliki beberapa sub tema.
3. Langka pembelajaran pembelajaran one question one minute, memungkinkan siswa untuk percaya diri, dan memungkinkan pengembangan bentuk sifat dan perilaku siswa dalam menjawab soal. Hal ini juga dapat dilihat dari angket respon minat dan motivasi siswa

Dari hasil penelitian yang diperoleh dari uraian sebelumnya agar proses belajar mengajar IPA lebih efektifdan memberikan hasil yang lebih optimal bagi peserta didik, maka disampaikan saran sebagai berikut:

1. Melaksanakan strategi pembelajaran one question one minute memerlukan persiapan yang cukup matang, sehingga guru mampu menentukan atau memilih topik yang benar-benar bisa diterapkan dengan strategi one question one minute dalam proses belajar mengajar sehingga diperoleh hasil belajar peserta didik yang optimal.

2. Untuk meningkatkan prestasi belajar peserta didik, guru hendaknya lebih sering melatih peserta didik dengan berbagai strategi pembelajaran, walaupun masih dalam taraf sederhana, dimana peserta didik nantinya dapat menemukan pengetahuan baru, memperoleh konsep, keterampilan memecahkan masalah pembelajaran, sehingga peserta didik mampu dan berhasil memecahkan masalahnya secara mandiri serta percaya diri.

\section{DAFTAR PUSTAKA}

Abidin, Zaenal. 2012. "Intuisi Siswa dalam Pemecahan Masalah Berdasarkan Gaya Kognitif Field Independent dan Field Dependent". Disertasi Program Pasca Sarjana, UNESA. 
Anggraena, Yogi, dkk. 2012. Panduan Pembelajaran dan Penilaian. Jakarta: Puskurbuk.

Carin, A.A. 1993. Guide Discovery Activities For Elementary School Science. $3^{\text {rd }}$ Ed. New York: Merril An In Print Of Macmillan Publishing Company.

Christou, Constantinos, Mousoulides, Nicholas, Pittalis, Marios, Pitta-Pantazi, Demetra, Sriraman, Bharath. 2005. "An Empirical Taxonomy of Problem Posing Processes". ZDM. 2005 Vol 37 No. 3, Page $149-158$.

Hariyono, E. 2002. Peningkatan Kualitas Pembelajaran Fisika SLTP Berdasarkan Model Penemuan Terbimbing (Guided Discovery). Tesis Magister

Ibrahim, M dan Nur, M. 2000. Pembelajaran Berdasarkan Masalah. Universitas Negeri Surabaya: University Press.

Kemp. Jerrold E. 2007. Designing Effective Instuction. USA: John Wiley \& Sons, Inc.

Kanginan, Marthen. 2002. Sains Fisika $3 A$ untuk SMP Kelas IX. Jakarta: Erlangga.

Kardi, S. 2002. Strategi Motivasi Model ARCS. Universitas Negeri Surabaya.

Kardi, S. 2003. Pembelajaran Penemuan. Universitas Negeri Surabaya.

Nur, M. 1998 Teori-teori Perkembangan. Surabaya: IKIP Surabaya

Nur, M dan Retno, P. w. 2000. Pembelajaran Berpusat Kepada Siswa dan Pendekatan Konstruktivis Dalam Pengajaran. Surabaya: Universitas Negeri Surabaya.
Lastiningsih, Netti. 2012. "Profil Berpikir Siswa SMP dalam Pengajuan Soal Berdasarkan Taksonomi Empirik Ditinjau dari Gaya Kognitif Field Independent dan Field Dependent". Tesis Program Pasca Sarjana, UNESA.

Lastiningsih, Netti. 2013. "Penerapan Strategi Pembelajaran Pengajuan Pertanyaan berdasarkan Gambar dan Tabel Siswa SMPN 6 Sidoarjo". Naskah Lomba Inobel, P2TK

PERMENDIKBUD No. 64 Tahun 2013 tentang Standar Isi.

PERMENDIKNAS No. 41 Tahun 2007 tentang Standar Proses.

SMPN1 Penajam Paser Utara, 2018. Kurikulum SMPN 1 Penajam Paser Utara Tahun Pelajaran 2018/2019

Suryanto. 1998. "Pembentukan Soal dalam Pembelajaran Matematika". Makalah Seminar Nasional di PPs IKIP Malang, 4 April 1998.

Suryobroto, B. 1997. Proses Belajar Mengajar Di Sekolah. Jakarta: Rineka Cipta.

Solso, Robert L. 2008. Psikologi Kognitif, Edisi Kedelapan. Jakarta: Erlangga.

Tim. Materi PLPG. 2011. Surabaya: UNESA.

Uno, Hamzah B. 2007. Model Pembelajaran Menciptakan Proses Belajar Mengajar yang Kreatif dan Efektif. Jakarta: Bumi Aksara.

Upu, Hamzah. 2003. Problem Posing dan Problem Solving dalam Pembelajaran Matematika. Bandung: Pustaka Ramadhan. 